\title{
Pasture allowance, duration, and stage of lactation-Effects on early and total lactation animal performance
}

\author{
A. Claffey, ${ }^{1,2}$ L. Delaby, ${ }^{3}$ E. Lewis, ${ }^{4}$ T. M. Boland, ${ }^{2}$ and E. Kennedy ${ }^{1 *}$ \\ ${ }^{1}$ Teagasc, Animal and Grassland Research and Innovation Centre, Moorepark, Fermoy, Co. Cork, P61 C996, Ireland \\ ${ }^{2}$ School of Agriculture and Food Science, University College Dublin, Belfield, Dublin 4, D04 N2E5, Ireland \\ ${ }^{3}$ INRA, Agro Campus Ouest, UMR 1348, Physiologie, Environnement et Génétique pour l'Animal et les Systèmes d'Elevage, \\ F-35590 Saint-Gilles, France \\ ${ }^{4}$ Devenish Nutrition Limited, Lagan House, 19 Clarendon Road, Belfast, BT1 3BG, United Kingdom
}

\begin{abstract}
Pasture availability in early spring can be limited due to climatic effects on grass production, increasing the likelihood of feed deficits in early lactation of springcalving pasture-based systems. We hypothesized that restricting pasture allowance (PA) when animals are at peak milk production will have more negative implications on milk production compared with restricting animals before this period. A total of 105 cows were assigned to 1 of 7 grazing treatments from March 14 to October 31, 2016 (33 wk). The control treatment was offered a PA to achieve a postgrazing sward height > $3.5 \mathrm{~cm}$ and mean pasture allowance of $15.5 \mathrm{~kg}$ of dry matter per cow. The remaining treatments were offered a PA representing $60 \%$ of that offered to the control for a duration of 2 or 6 wk from March 14 (mid-March; MMx2 and MMx6), March 28 (end of March; EMx2 and EMx6), or April 11 (mid-April; MAx2 and MAx6). Within grazing treatment, animals were also assigned to 1 of 2 calving dates (early and late) based on days in milk (DIM) on March 14. Early calved (EC) cows were $\geq 36$ DIM, while late calved (LC) were $\leq 35$ DIM. Restricting PA for 2 and 6 wk reduced daily milk yield $(-1.6$ and $-2.2 \mathrm{~kg} / \mathrm{cow}$, respectively), cumulative milk protein yield $(-4.0$ and $-6.3 \mathrm{~kg} /$ cow, respectively), and cumulative milk solids yield $(-5.8$ and $-9.5 \mathrm{~kg} /$ cow, respectively) in the first $10 \mathrm{wk}$ of the experiment. Daily milk yield was similar across the treatments at the end of the 33 -wk period $(16.8 \mathrm{~kg} / \mathrm{cow}$, average of all treatments), as was daily milk solids yield $(1.40 \mathrm{~kg} /$ cow). Cows in the EC group produced less milk over the first $10 \mathrm{wk}$ of the experiment $(20.0 \mathrm{~kg} / \mathrm{cow}$ per day $)$ compared with the LC animals $(22.1 \mathrm{~kg} /$ cow per day). However, body weight was greater $(+15 \mathrm{~kg} / \mathrm{cow})$ in the EC animals compared with the LC, while body condi-
\end{abstract}

Received October 2, 2018.

Accepted May 28, 2019.

*Corresponding author: emer.kennedy@teagasc.ie tion score was similar (2.85). This outcome indicates that animals that are restricted later in early lactation (circa onset of peak milk production) partition a greater proportion of available energy to maintenance, resulting in greater losses in milk production. These data indicate that despite the immediate reduction in milk production, restricting intake of grazing cows to $80 \%$ of that required to achieve spring grazing targets for postgrazing sward height for up to 6 wh may be used as a method of managing short-term pasture deficits on farm with minimal effects on total lactation performance.

Key words: dairy cow, early lactation stage, pasture allowance

\section{INTRODUCTION}

Grazed grass is the cheapest feed available to support milk production in intensive pasture-based systems (Finneran et al., 2010). However, grass availability in spring can be highly variable due to low growth rates over the winter period (November to February in Ireland; Hurtado-Uria et al., 2013). Furthermore, PastureBase Ireland data (Hanrahan et al., 2017) indicate large variation in spring growth (February to April in Ireland) on farm, with year-to-year variation as high as $40 \%$. As a result, grass availability during the first and second grazing rotations (February to early April and early to late April for first and second grazing rotation, respectively, in Ireland) can be insufficient to meet herd demand in early lactation. This shortfall can limit the regrowth potential of the grazed sward in spring (Brereton and McGilloway, 1999) and result in possible feed deficits, particularly at the end of the first rotation and throughout the course of the second grazing rotation. Consequently, feed budgeting may be particularly challenging on farm because feed deficits may arise over a prolonged period, coinciding with early lactation in spring-calving pasture-based systems. Greater repercussions may also exist for restricting ani- 
mals in the second grazing rotation because it generally coincides with the weeks preceding the breeding season, potentially the peak milk production, and the onset of peak DMI for the majority of the herd in compact spring-calving pasture-based systems.

In pasture-based systems, early lactation milk production is closely aligned with pasture allowance (PA) (Kennedy et al., 2007; McEvoy et al., 2008), with restricted PA generally resulting in increased pasture use, but an immediate decrease in DMI and milk production (Kennedy et al., 2007; Roche, 2007; Burke et al., 2010; Ganche et al., 2013; Kay et al., 2013). Numerous grazing studies have been carried out to examine the effects of PA in spring over a period of at least $10 \mathrm{wk}$ in early lactation (Kennedy et al., 2007; McEvoy et al., 2008; Ganche et al., 2013). In recent years, studies have investigated shorter periods of reduced PA, which may be more applicable to on-farm grazing scenarios (Burke et al., 2010; Kennedy et al., 2015; Cummins et al., 2015). Kennedy et al. (2015) reported that a 2-wk reduction in PA (60 and $80 \%$ of that offered to control treatment, $14 \mathrm{~kg}$ of $\mathrm{DM} / \mathrm{cow}$ ) did not have a carryover effect on milk production over a 10 -wk period. However, when a $60 \% \mathrm{PA}$ was maintained for $6 \mathrm{wk}(80 \%$ of control DMI; Cummins et al., 2015) the effects were still evident in the $4 \mathrm{wk}$ after the restriction $(-3 \mathrm{~kg}$ of milk/cow per day; Kennedy et al., 2015). Burke et al. (2010) investigated the effect of a short-term (2-wk) severe restriction (50\% of control cow intake) at the onset of breeding ( $\sim 63$ DIM). They reported an immediate reduction in milk production $(25 \%)$ and a $7 \%$ decrease in pregnancy rate in the first 6 wk of breeding. Similarly, Roche (2007) and Kay et al. (2013) reported large reductions in immediate milk production and long-term negative effects (carryover effect of underfeeding present for $\sim 10$ wk post restriction) when cows were severely ( $\sim 40 \%$ reduction in DMI compared with control) restricted for 5 and $3 \mathrm{wk}$, respectively, during early lactation (immediately postpartum and from 34 DIM). These results demonstrate 2 key factors that are associated with the effect of restriction on animal production: the proportionate drop in DMI and the duration for which DMI is restricted (Delaby et al., 2009). Because the aforementioned studies have a carryover period ranging from 4 to $20 \mathrm{wk}$, further investigation is required to determine if short-term moderate restrictions in PA affect total lactation performance.

Herbage deficits can arise at several critical periods during the lactation of a cow, such as the onset of peak DMI and peak milk production. This possibility warrants further research into the effects of short-term reductions in PA and whether such reductions have an interactive effect with time from calving on immediate animal performance and over the full lactation. We hypothesize that restricting animals that are calved longer and thereby have potentially reached the onset of peak milk production will reduce milk production more than in animals that are restricted prior to this point in lactation. The work of Baird et al. (1972) suggests that after peak milk yield, the precedence of energy resources given to milk production declines, in contrast to a greater partitioning of energy toward milk synthesis before this point. The objective of the current study was to determine the effects of varying PA, allocated for 2 durations, on early and late spring-calved cows at different time points in the first and second grazing rotation and on immediate and total lactation dairy cow production.

\section{MATERIALS AND METHODS}

This experiment was carried out at the Teagasc, Animal \& Grassland Research and Innovation Centre, Moorepark, Fermoy, Co. Cork $\left(52^{\circ} 7^{\prime} 3^{\prime \prime} \mathrm{N}, 8^{\circ} 16^{\prime} 42^{\prime \prime} \mathrm{W}\right)$ from March 14 to October 31, 2016. The Teagasc Animal Ethics Committee granted ethical approval for the study to be carried out (TAEC100/2015). The Health Products Regulatory Authority, Ireland, provided project authorization (AE19132/P045) as required under Statutory Instrument No. 543 of 2012 for the Protection of Animals Used for Scientific Purposes.

\section{Experimental Design}

A total of 105 cows were assigned to a randomized design experiment consisting of 7 treatments $(\mathrm{n}=15)$ on March 14, 2016. Two durations of restricted PA ( $60 \%$ of the control PA) were compared (2 and 6 wk) to an unrestricted treatment (control). The control was offered a PA to achieve a target postgrazing sward height (Post-GSH) of $3.5 \mathrm{~cm}$ (measured daily using a rising plate meter). Pasture allowance was adjusted daily to achieve this target Post-GSH.

The treatments were as follows. In the control group, animals were allocated a PA to achieve a Post-GSH of $3.5 \mathrm{~cm}$ from the experimental start date. In the restricted groups, animals were allocated to a reduced PA representing $60 \%$ of the control PA beginning on March 14 (mid-March, MM), for a duration of 2 wk (MMx2); March 14, for a duration of 6 wk (MMx6); March 28 (end-March, EM), for a duration of 2 wk (EMx2); March 28, for a duration of 6 wk (EMx6); April 11 (mid-April, MA), for a duration of $2 \mathrm{wk}$ (MAx2); and April 11, for a duration of 6 wk (MAx6).

The median calving date of the herd was identified, and cows were assigned to 1 of 2 groups depending on 
their calving date relative to the median. Early calved (EC) cows were categorized as animals that were 36 DIM or greater at the beginning of the experimental period. These animals ranged from 36 to 57 DIM and averaged 41 DIM at the beginning of the experiment. The remaining cows were assigned to a late calved group (LC), which consisted of animals 7 to 35 DIM (mean = 24) at the beginning of the experimental period.

Cows were balanced based on breed (HolsteinFriesian, 50 cows; Holstein-Friesian $\times$ Jersey, 55 cows), calving group (EC or LC), actual calving date (February $10, \pm 11 \mathrm{~d}$; mean $\pm \mathrm{SD}$ ), parity (30 animals in their first lactation and 75 animals in their second or greater lactation), and pre-experimental milk production gathered during the $2 \mathrm{wk}$ before the start of the experiment [milk yield, $24.2 \pm 3.82 \mathrm{~kg} / \mathrm{cow}$ per day; milk solids yield ( $\mathrm{kg}$ of fat $+\mathrm{kg}$ of protein), $2.03 \pm 0.422 \mathrm{~kg} /$ cow per day; milk protein concentration, $33.0 \pm 3.30 \mathrm{~g} /$ $\mathrm{kg}$ milk; milk fat concentration, $51.7 \pm 8.87 \mathrm{~g} / \mathrm{kg}$ of milk; BW, $502 \pm 71.2 \mathrm{~kg}$; and BCS, $3.00 \pm 0.157]$. The economic breeding index profile of the herd was €204 on average, with a breakdown of $€ 66$ for milk, $€ 103$ for fertility, and $€ 18$ for maintenance (Berry et al., 2005).

\section{Grazing Management}

Before the experiment, all cows were allocated fresh grass ( $8 \mathrm{~kg}$ of DM/cow) and up to $4 \mathrm{~kg}$ of concentrate per day. The concentrate was made up of soybean meal (300 g/ kg of fresh weight), beet pulp/molasses (155 g/ $\mathrm{kg})$, barley $(150 \mathrm{~g} / \mathrm{kg})$, maize $(130 \mathrm{~g} / \mathrm{kg})$, maize distillers $(120 \mathrm{~g} / \mathrm{kg})$, rapeseed meal $(75 \mathrm{~g} / \mathrm{kg})$, Megalac $(33 \mathrm{~g} /$ kg; Volac Wilmar Feed Ingredients Ltd., Hertfordshire, UK), maize/beet $(25 \mathrm{~g} / \mathrm{kg})$, acid buff $(7 \mathrm{~g} / \mathrm{kg})$, and salt $(5 \mathrm{~g} / \mathrm{kg})$; the $\mathrm{CP}$ content was $160 \mathrm{~g} / \mathrm{kg}$ of fresh weight. Concentrate was reduced gradually and was removed from the diet $1 \mathrm{wk}$ before the start of the experiment.

Period 1 (Experimental Wk 1-10). From the experimental start date, the control group was offered a PA to target a Post-GSH of $3.5 \mathrm{~cm}$ (Figure 1), as recommended for spring grazing management (Ganche et al., 2013) to achieve the optimum balance between grass utilization and animal performance. The MMx2 and MMx6 groups began their respective PA restriction from this point also and received a PA representing $60 \%$ of that offered to the control. The remaining treatments (EMx2, EMx6, MAx2, and MAx6) were offered $50 \%$ of the total PA offered to the control by day and ad libitum grass silage by night until their respective $60 \%$ PA began, at which point they received grass only. Cows returned to the same PA as the control when their respective $60 \%$ PA period had ceased.

Fresh pasture was provided after each milking and access to water was provided at all times. Pasture was allocated to $3.5 \mathrm{~cm}$, but Post-GSH was not restricted; therefore, cows could further increase their DMI by

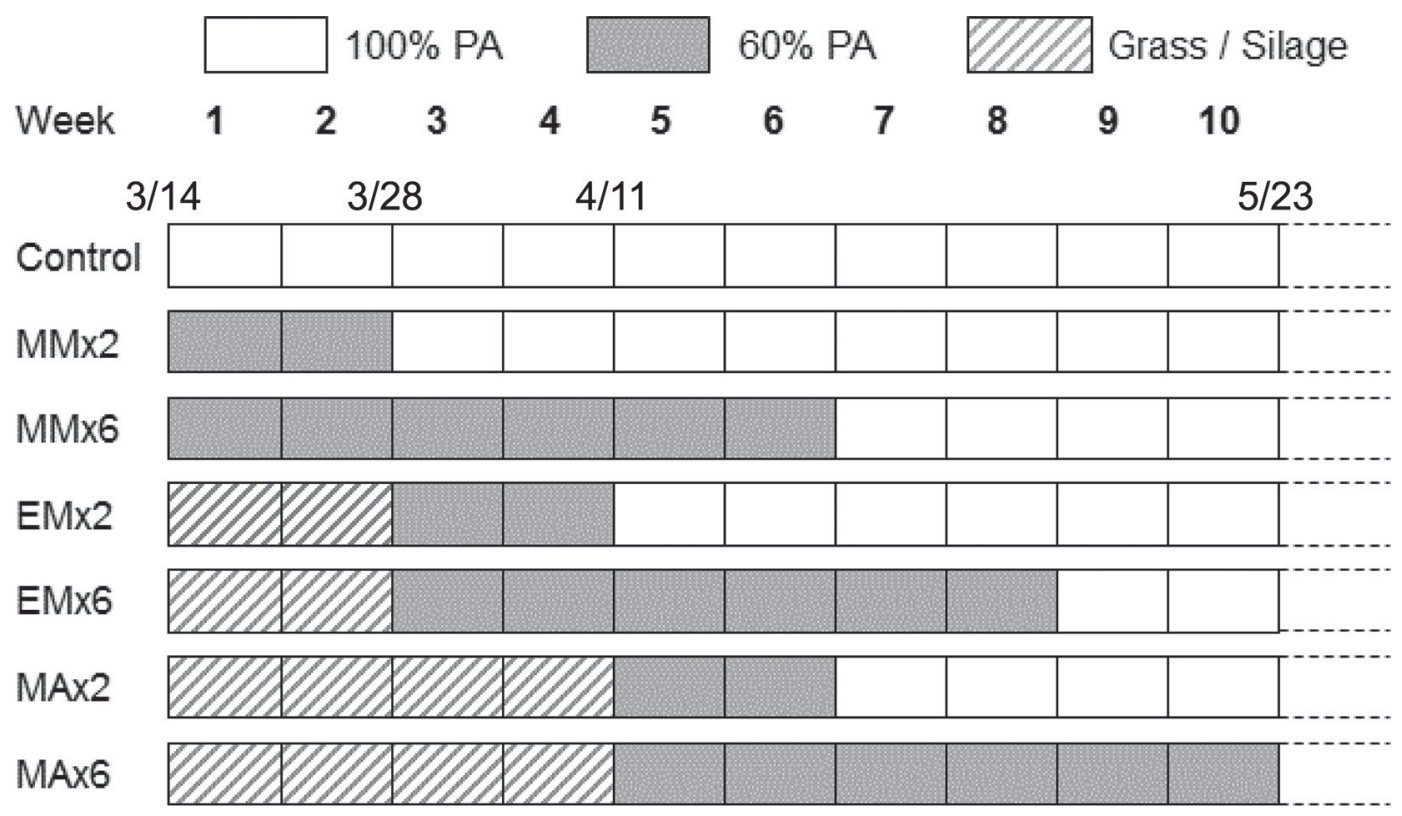

Figure 1. Diagram representing the feed allocation [grass/silage, $60 \%$ pasture allowance (PA), $100 \%$ PA] of each grazing treatment: control $=$ $100 \%$ PA; MMx2 = 60\% PA, March $14(3 / 14)$ for 2 wk; MMx6 = 60\% PA, March 14 for 6 wk; EMx2 = 60\% PA, March 28 (3/28) for 2 wk; EMx6 $=60 \%$ PA, March 28 for 6 wk; MAx2 =60\% PA, April 11 (4/11) for 2 wk; MAx6 = 60\% PA, April 11 for 6 wk, in period 1 of the experiment. 
grazing below $3.5 \mathrm{~cm}$. To maintain a Post-GSH of 3.5 $\mathrm{cm}$ for the control, PA was adjusted daily, thereby catering for the increasing demand of the cows due to stage of lactation. Consequently, all other treatments increased proportionately. While treatments were imposed, herds grazed separately but adjacent to one another, separated by temporary electric fences. Paddocks were dusted with calcined magnesite to alleviate the risk of grass tetany. On-off grazing was practiced to minimize damage in inclement weather, as described by Kennedy et al. (2011), whereby the cows were removed from pasture after $3 \mathrm{~h}$ of grazing and housed until the following milking. During this period they had access to water and cubicle accommodation but no access to feed.

Period 2 (Experimental Wk 11-33). In wk 11 (May 23) of the experiment, all PA reductions had ceased and cows grazed as a single herd and were offered a PA to achieve a residual above $4.0 \mathrm{~cm}(16.3 \mathrm{~kg}$ of $\mathrm{DM} /$ cow per day) for the remainder of their lactation, as recommended for midseason grazing management (McEvoy et al., 2008; Ganche et al., 2013). Pasture was allocated on a 24-h basis from this point onward.

\section{Sward Measurements}

Pregrazing herbage mass (measured above $3.5 \mathrm{~cm}$ ) was measured twice weekly by cutting 8 strips (approximately $1.2 \mathrm{~m}$ wide $\times 10 \mathrm{~m}$ long) from the grazing area with an Etesia mower (Etesia UK Ltd., Warwick, UK). The herbage from each strip was collected and weighed, and a subsample (300 g) was collected from each strip. From this subsample, $100 \mathrm{~g}$ was weighed and dried at $90^{\circ} \mathrm{C}$ for $16 \mathrm{~h}$ to determine DM content. A composite sample from each paddock ( $\sim 300 \mathrm{~g})$ was dried at $60^{\circ} \mathrm{C}$ for $48 \mathrm{~h}$. It was then milled through a $1-\mathrm{mm}$ screen using a Cyclotech 1093 Sample Mill (Foss, Hillerød, Denmark) and stored. Compressed sward heights were also recorded pre- and postcutting by taking 10 measurements from each strip, using a rising plate meter (Jenquip Rising Plate Pasture Meters, Feilding, New Zealand; diameter $355 \mathrm{~mm}$ and $3.2 \mathrm{~kg} / \mathrm{m}^{2}$ ). The average paddock pregrazing herbage mass $>3.5 \mathrm{~cm}$ was then calculated according to the following equation:

$$
\begin{gathered}
\text { Pregrazing herbage mass }(\mathrm{kg} \text { of } \mathrm{DM} / \mathrm{ha})= \\
{[\text { weight }(\mathrm{kg}) \times \mathrm{DM} \% \times 10,000] /} \\
\text { area }(\text { length } \times 1.2 \mathrm{~m}) .
\end{gathered}
$$

Pregrazing sward height (Pre-GSH) was measured before each grazing by taking 30 measurements across the 2 diagonals of each grazing treatment, using the ris- ing plate meter as described above. This procedure was repeated after each grazing to determine the Post-GSH from each grazing treatment.

Herbage removed ( $\mathrm{kg}$ of $\mathrm{DM} / \mathrm{cow}$ ) was calculated daily to estimate DMI of the treatment groups, using the following equation:

$$
\begin{gathered}
(\{\text { Pre-GSH }(\mathrm{cm})-\text { Post-GSH }(\mathrm{cm})] \times \text { sward density }\} \\
\quad \times \text { area available for grazing }) / \text { no. of animals }
\end{gathered}
$$

A selection of herbage $(300 \mathrm{~g})$, representative of that selected by the cows, was taken weekly from each treatment using Gardena hand shears (Accu 90, Gardena International GmbH, Ulm, Germany), noting the previous defoliation height of the cows (cut to achieve the same Post-GSH of the cows from the previous day). The samples were stored at $-18^{\circ} \mathrm{C}$. The frozen herbage was bowl-chopped (Muller, Type MKT 204 Special, Saarbrücken, Germany) and freeze-dried at $-50^{\circ} \mathrm{C}$ for $120 \mathrm{~h}$. The samples were then milled through a 1-mm screen using a Cyclotec 1093 Sample Mill (Foss) for subsequent analysis.

Sward nutritive value of all selected herbage samples was determined using near-infrared reflectance spectroscopy for organic matter digestibility (OMD), CP, $\mathrm{ADF}, \mathrm{NDF}$, and ash content (adapted from the work of Burns et al. 2011).

\section{Animal Measurements}

Cows were milked twice daily at 0700 and $1530 \mathrm{~h}$. Individual yields $(\mathrm{kg} / \mathrm{cow})$ were recorded at each milking (Dairymaster, Causeway, Ireland). Milk composition was measured weekly from one successive evening and morning milking. The concentrations of protein, fat, and lactose were determined using a Milkoscan 203 (Foss Electric, Hillerød, Denmark).

Body weight and BCS were measured on a weekly basis. All cows were weighed using an electronic portable weighing scale and Winweigh software package (Tru-Test Limited, Auckland, New Zealand). Body condition score was recorded weekly and was scored by an experienced independent observer using a 1 to 5 scale $(1=$ emaciated and $5=$ extremely fat $)$ with 0.25 increments (Edmonson et al., 1989).

\section{Statistical Analysis}

All PA treatments were completed within the first 10 wk of the experimental period, and therefore, average and cumulative production was analyzed at this point (period 1, wk 1-10) and total lactation (wk 1-33, as 
a proportion of the total herd was dried off in wk 34 based on expected calving dates for the following year). The average daily milk yield; daily milk fat, protein, and lactose concentrations; and daily milk solids yield for the aforementioned periods were analyzed. Cumulative analysis was also carried out for milk fat yield, milk protein yield, milk lactose yield, and milk solids yield. Body weight and BCS at the end of period 1 (average of wk 9 and 10) and end of lactation (average of wk 32 and 33) were also analyzed.

All statistical analysis was carried out using SAS Version 9.4 (SAS Institute Inc., Cary, NC). Analysis of all herbage variables was carried out using PROC MIXED models in SAS. Daily Pre-GSH, Post-GSH, pregrazing herbage mass, daily herbage allowance (including silage offered), and herbage removed (including silage offered) were analyzed over period 1 . The model contained terms for treatment, rotation, and week and for their interactions.

Three cows were removed from the analysis due to health problems encountered during the experimental period that were not associated with the experimental treatment; therefore, the analysis was carried out on 102 cows. The effect of grazing treatment (1-7), calving group ( 1 or 2 ), parity ( 1 or 2$)$, breed ( 1 or 2 ), and all their first interactions on animal production variables were analyzed using PROC MIXED models in SAS. Contrasts were also applied within the PROC MIXED models to determine the effect of restriction (control vs. all $60 \%$ PA treatments), duration (2- vs. 6-wk PA restriction), the linear and quadratic response to the time point at which the restriction was applied (MM, EM, or MA), and the linear and quadratic response of the interaction between the point at which the restriction was applied (MM, EM, or MA) and the duration (2 vs. 6 wk). The model contained terms associated with animal production including the individual covariate specific to the variable. All covariates were measured for the $2 \mathrm{wk}$ before the experimental start date and were centered within breed and parity to reduce the effect of multicollinearity and to improve the precision of the statistical analysis.

\section{RESULTS}

\section{Sward Characteristics and Pasture Allowance}

A significant interaction $(P<0.001)$ occurred between treatment and week; when PA was restricted to $60 \%$ of the control PA, the restricted treatments differed in Post-GSH, daily herbage allowance, and kilograms of herbage removed relative to unrestricted treatments in the respective week. Grazing treatment had an effect on Pre-GSH $(P<0.05)$ in period 1 (first 10 wk of

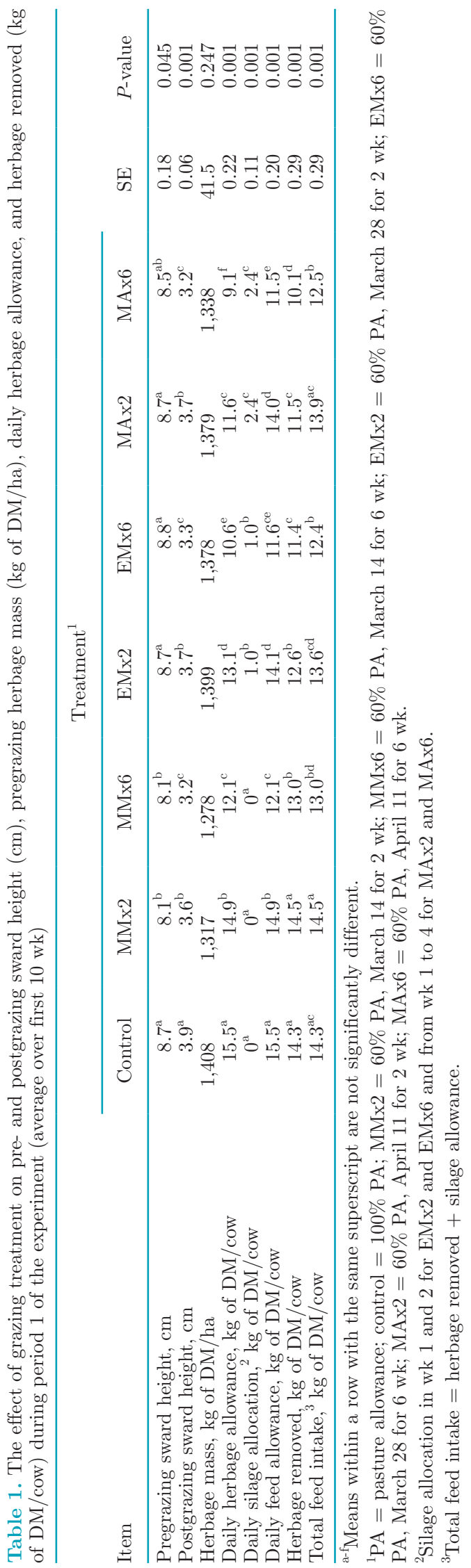


experiment). The control, EMx2, EMx6, and MAx2 treatments had greater Pre-GSH $(+0.6 \mathrm{~cm}$, Table 1$)$ compared with the MMx2 and MMx6 treatments (8.1 $\mathrm{cm})$. The MAx6 was intermediate and similar to all treatments $(8.5 \mathrm{~cm})$. The control had greater Post-GSH $(P<0.001 ;+0.5 \mathrm{~cm})$ during period 1 compared with all other treatments $(3.5 \mathrm{~cm})$. The 2 -wk restricted PA treatments had greater Post-GSH $(+0.5 \mathrm{~cm})$ compared with the 6 -wk restricted PA treatments $(3.2 \mathrm{~cm})$. Pregrazing herbage biomass was similar for all treatments (1,357 kg DM/ha, above $3.5 \mathrm{~cm})$.

The control had a greater daily feed allowance (PA + silage allocation in first $4 \mathrm{wk} ; 15.5 \mathrm{~kg}$ of DM/cow) than all other treatments $(13.0 \mathrm{~kg}$ of $\mathrm{DM} /$ cow $P<0.001)$. The MMx2 also had a greater daily feed allowance than the remainder of the restricted PA treatments $(14.9 \mathrm{~kg}$ of DM/cow). The EMx2 and MAx2 had a similar daily feed allowance of $14.1 \mathrm{~kg}$ of DM/cow, which was greater than that in all treatments that were restricted for 6 wk. The MMx6 and EMx6 were similar (11.9 kg of DM/ cow), while the MMx6 had a greater daily feed allowance $(+0.6 \mathrm{~kg}$ of $\mathrm{DM} / \mathrm{cow})$ compared with the MAx6 (11.5 kg DM/cow), which was similar to the EMx6. All 2-wk restricted PA treatments achieved a similar level of estimated total feed intake compared with the control (14.1 kg of DM removed/cow); however, the MMx2 was greater $(+0.9 \mathrm{~kg}$ of DM removed/cow $)$ compared with the EMx2 (13.6 kg of DM removed/cow). All 6-wk restricted PA treatments had similar levels of estimated total feed intake $(12.6 \mathrm{~kg}$ of $\mathrm{DM} / \mathrm{cow})$.

Following period 1 of the experiment, all animals grazed as one herd. The Pre- and Post-GSH were 10.7 \pm 2.01 and $4.5 \pm 0.50 \mathrm{~cm}$, respectively, during period 2. Pasture allowance and DM removed were $16.3 \pm 0.93$ and $14.8 \pm 2.11 \mathrm{~kg}$ of $\mathrm{DM} / \mathrm{cow}$, respectively. Due to shortages in herbage that arose over period 2 of the experiment, $116 \mathrm{~kg}$ of concentrate was also offered to each cow. Pregrazing herbage biomass was $1,961 \pm 509.9 \mathrm{~kg}$ of $\mathrm{DM} /$ ha during period 2.

\section{Sward Nutritive Value}

Grazing treatment had no effect on sward nutritive value in period 1 . Organic matter digestibility and $\mathrm{CP}$ content were similar for all treatments (Table 2; 868 and $201 \mathrm{~g} / \mathrm{kg}$ of DM, respectively). Acid detergent fiber and NDF concentrations were similar for all treatments (243 and $361 \mathrm{~g} / \mathrm{kg}$ of DM, respectively). Ash content was $57 \mathrm{~g} / \mathrm{kg}$ of DM in period 1 and was similar for all treatments.

Sward nutritive value for period 2 of the experiment was $856 \pm 22.7$ and $214 \pm 30.8 \mathrm{~g} / \mathrm{kg}$ of $\mathrm{DM}$ for $\mathrm{OMD}$, and $\mathrm{CP}$, respectively. Acid detergent fiber and NDF were $269 \pm 27.0$ and $399 \pm 36.4 \mathrm{~g} / \mathrm{kg}$ of DM, respectively. Ash content was $64 \pm 21.5 \mathrm{~g} / \mathrm{kg}$ of $\mathrm{DM}$ for period 2. All animals grazed as one herd during this period, and therefore, sward nutritive value was similar for all treatments.

\section{Animal Production}

Because differences within grazing treatments based on the calendar stage of restriction (MM, EM, and MA) were minimal, the results of the contrasts focusing on the effects of restriction and duration are presented first. No interaction was present between breed and grazing treatment or between parity and grazing treatment for period 1, so only the main effects are reported. Similarly, because no interactions were found between calving group and grazing treatment, only the main effects of calving group will be presented where an interaction does not exist.

Three 2-way interactions were observed. The first was an interaction between breed and parity for BW; however, this finding was an artifact of the greater mature BW of the Holstein-Friesian animals. An interaction was also present between parity and calving group for milk protein concentration, with the primiparous animals being similar, but the multiparous EC having

Table 2. The effect of grazing treatment on OM digestibility, CP, ADF, NDF, and ash content of selected herbage samples collected during period 1 of the experiment (average over first $10 \mathrm{wk}$ )

\begin{tabular}{|c|c|c|c|c|c|c|c|c|c|}
\hline Item & \multicolumn{7}{|c|}{ Treatment $^{1}$} & $\mathrm{SE}$ & $P$-value \\
\hline OM digestibility, $\mathrm{g} / \mathrm{kg}$ & 868 & 868 & 869 & 865 & 864 & 875 & 870 & 7.7 & 0.967 \\
\hline $\mathrm{ADF}, \mathrm{g} / \mathrm{kg}$ of $\mathrm{DM}$ & 243 & 245 & 242 & 245 & 243 & 241 & 244 & 4.4 & 0.990 \\
\hline $\mathrm{NDF}, \mathrm{g} / \mathrm{kg}$ of DM & 363 & 370 & 363 & 360 & 356 & 357 & 358 & 7.2 & 0.841 \\
\hline Ash, $\mathrm{g} / \mathrm{kg}$ of $\mathrm{DM}$ & 57 & 52 & 50 & 62 & 60 & 59 & 56 & 3.6 & 0.251 \\
\hline
\end{tabular}

${ }^{1} \mathrm{PA}=$ pasture allowance; control $=100 \% \mathrm{PA} ; \mathrm{MMx} 2=60 \% \mathrm{PA}$, March 14 for $2 \mathrm{wk}$;Mx6 $=60 \%$ PA, March 14 for $6 \mathrm{wk}$; $\mathrm{Ex} 2=60 \%$ PA, March 28 for 2 wk; EMx6 = 60\% PA, March 28 for 6 wk; MAx2 =60\% PA, April 11 for 2 wk; MAx6 =60\% PA, April 11 for 6 wk. 
a much greater milk protein concentration compared with the LC. Similarly, an interaction existed between parity and calving group for milk protein yield, with the multiparous animals having similar milk protein yield, but the LC primiparous animals having a greater milk protein yield compared with their EC counterparts. Only the main treatment effects will be reported from this point.

\section{Effect of Restriction on Animal Production During Period 1}

Restricting PA in early lactation reduced daily milk yield by $1.9 \mathrm{~kg}$ milk/cow $(P<0.01$, Table 3$)$ in a comparison of the control with all other grazing treatments. Restriction had no effect on milk fat, protein, and lactose concentrations in period 1 (45.7, 33.3, and $48.9 \mathrm{~g} / \mathrm{kg}$ of milk, respectively). In all cases where there was no difference between the control and the restricted treatments, the results are presented as the average of all 7 treatments. Daily milk solids yield (fat and protein) was reduced by $0.11 \mathrm{~kg}$ of milk solids/cow as a result of restricted PA $(P=0.057)$, which resulted in a cumulative reduction of $7.6 \pm 3.61 \mathrm{~kg}$ of milk sol$\mathrm{ids} /$ cow by the end of period 1. Cumulative milk fat yield was similar for all treatments $(67.6 \pm 2.6 \mathrm{~kg} /$ cow). Imposing a restriction in early lactation resulted in an average reduction of milk protein yield by $5.15 \pm$ $1.32 \mathrm{~kg} / \mathrm{cow}(P<0.001)$ and reduced milk lactose yield $(-7.1 \pm 2.06 \mathrm{~kg} / \mathrm{cow} ; P<0.01)$ over the 10 -wk period compared with all other treatments. Body weight and BCS were similar for all treatments at the end of period 1 (453 kg and 2.84 BCS units).

\section{Effect of Duration of Restriction on Animal Production During Period 1}

The 2- and 6-wk treatments were compared within the contrasts applied during analysis. The duration of the PA restriction had no significant effect (Table 3) on average daily milk yield, despite a reduction of $0.6 \mathrm{~kg}$ of milk/cow per day for 10 wk when PA was restricted for 6 wk compared with 2 wk. Duration had no effect on milk fat concentration ( $46.4 \mathrm{~g} / \mathrm{kg}$ of milk). Offering a reduced PA for 6 wk resulted in lower milk protein concentration $(P<0.01 ;-1.1 \mathrm{~g} / \mathrm{kg}$ of milk per cow per day for 10 wk) compared with a 2 -wk reduction. Duration did not have an effect on milk lactose concentration $(48.9 \mathrm{~g} / \mathrm{kg}$ of milk). Duration had no effect on milk solids yield when PA was restricted for $6 \mathrm{wk}$ $(-0.06 \pm 0.052 \mathrm{~kg}$ of milk solids/cow per day for 10 wk) compared with $2 \mathrm{wk}(1.68 \mathrm{~kg}$ of milk solids/cow per day).

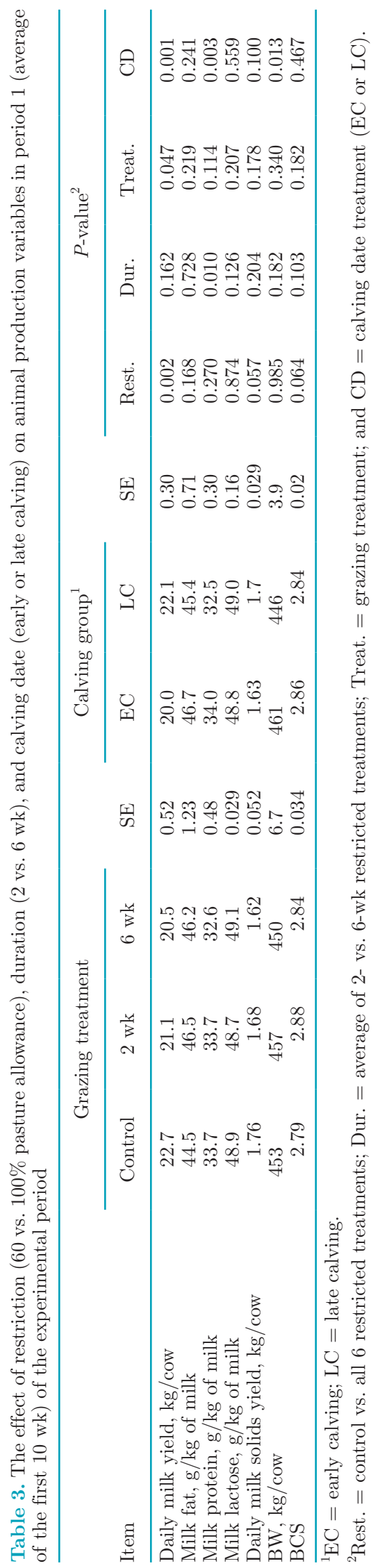


Duration of the restriction had no effect on milk fat and lactose yields during the $10 \mathrm{wk}(67.3$ and $71 \mathrm{~kg} /$ cow, respectively). Duration had a significant effect on milk protein yield $(P<0.05)$, with cows restricted for 2 wk producing $2.3 \mathrm{~kg} /$ cow more protein in the 10 -wk period compared with cows restricted for 6 wk at pasture. Body weight and BCS at the end of the 10-wk period were not affected by the duration of PA restriction (454 $\mathrm{kg}$ and 2.86 BCS units).

\section{Effect of Timing of Restriction on Animal Production During Period 1}

The calendar timing of the restriction imposed had minimal effects on the majority of the animal production variables analyzed. Time point of restriction had a significant quadratic effect $(P<0.05)$ on milk fat concentration, with the EM treatments having lower milk fat $(-2.7 \mathrm{~g} / \mathrm{kg}$ of milk) compared with the MA (47.5), while the MM treatment was intermediate to both $(46.8 \mathrm{~g} / \mathrm{kg}$ of milk). A quadratic interaction $(P<$ 0.05 ) was also present between time point of restriction for milk lactose concentration, with the EM treatments having greater milk lactose concentration $(+6.0 \mathrm{~g} / \mathrm{kg}$ of milk) compared with the MM, while the MA was intermediate to both $(48.8 \mathrm{~g} / \mathrm{kg}$ of milk).

\section{Effect of Calving Group on Animal Production in Period 1}

Restricting PA of cows in the EC group ( $\geq 36$ DIM) resulted in lower milk yield $(-2.1 \mathrm{~kg}$ of milk/cow per day; Table 3) compared with the LC cows ( $\leq 35$ DIM; $22.1 \mathrm{~kg}$ of milk/cow per day). During this period of the experiment, the EC restricted cows produced $15 \%$ less milk (19.7 kg of milk/cow per day) compared with their respective control treatment $(23.2 \mathrm{~kg}$ of milk/cow per day), while the LC restricted cows produced $5 \%$ less milk $(-1.1 \mathrm{~kg}$ of milk/cow per day) compared with their respective control treatment. Milk fat concentration was similar for both groups $(46.0 \mathrm{~g} / \mathrm{kg}$ of milk). Cows restricted in the LC group had lower milk protein concentration $(P<0.01 ;-1.5 \mathrm{~g} / \mathrm{kg}$ of milk) compared with cows in EC group during period $1(34.0 \mathrm{~g} / \mathrm{kg}$ milk). Milk lactose concentration was similar (48.9 g/ $\mathrm{kg}$ of milk) for both groups. Calving group had no effect on average daily milk solids yield $(P=0.1)$, despite cows restricted in the LC group producing more milk solids compared with the EC cows (1.70 vs. $1.63 \mathrm{~kg}$ of milk solids/cow per day, respectively). Calving date had a significant effect on BW at the end of period $1(P$ $<0.05)$; cows restricted in the LC had lower BW $(-15$ $\mathrm{kg}$ ) at the end of $10 \mathrm{wk}$ compared with the EC cows
(461 kg, respectively). Body condition score was not affected by calving group (2.85 BCS units).

\section{Effect of Restriction, Duration, and Timing of Restriction on Cumulative Animal Production During the Full Experimental Period}

We found no effect of grazing treatment on any of the production variables analyzed at the end of the 33-wk period, nor did we find any interactions with breed, parity, or calving group. Daily milk and milk solids yields were similar across all treatments $[16.8 \mathrm{~kg}$ of milk/cow (Figure 2) and $1.40 \mathrm{~kg}$ of milk solids/cow; Table 4]. Milk composition was similar across all treatments $(46.8,36.8$, and $47.5 \mathrm{~g} / \mathrm{kg}$ of milk for milk fat, protein, and lactose concentrations, respectively). Body weight and BCS were similar for all treatments (489 $\mathrm{kg}$ and 2.86 BCS units) at the end of the experiment. A quadratic interaction $(P<0.01)$ was also present between time point and duration of restriction for BCS, with the MAx6 having lower BCS ( -0.1 BCS units) compared with the MAx2 (2.91 BCS units), while the MM and EM treatments were similar for their respective durations (2.87 and 2.85 BCS units, respectively).

\section{Effect of Calving Group on Cumulative Animal Production During the Full Experimental Period}

Calving group had a significant effect on milk yield $(P<0.01)$ over the full experimental period (33 wk), with animals in the LC group producing greater daily milk yields $(+1.2 \mathrm{~kg}$ of milk/cow) compared with cows in the EC group (16.1 kg of milk/cow). Milk fat and lactose concentration were not affected by calving group (47.2 and $47.6 \mathrm{~g} / \mathrm{kg}$ of milk, respectively). Milk protein concentration was greater for the cows in the EC group $(P<0.05 ;+1.7 \mathrm{~g} / \mathrm{kg}$ of milk) compared with the LC cows $(35.9 \mathrm{~g} / \mathrm{kg}$ of milk).

Milk fat yield and milk protein yield were similar across both calving groups for the full experimental period (181 and $141 \mathrm{~kg} / \mathrm{cow}$, respectively). Consequently, average daily milk solids yield was similar for both groups (1.39 kg of milk solids/cow). Milk lactose yield was $16 \mathrm{~kg} / \mathrm{cow}$ less for the EC group compared with the LC group (191 kg/cow). Calving group had a significant effect on BW at the end of the experimental period, with restricted cows in the EC group having significantly greater BW $(P<0.01 ;+19 \mathrm{~kg})$ compared with those in the LC group $(480 \mathrm{~kg})$. Calving group also had an effect on BCS $(P<0.01)$ at the end of the 33-wk experimental period, with the EC cows having a BCS that was 0.09 units greater than that of the LC cows (2.82 BCS units). 


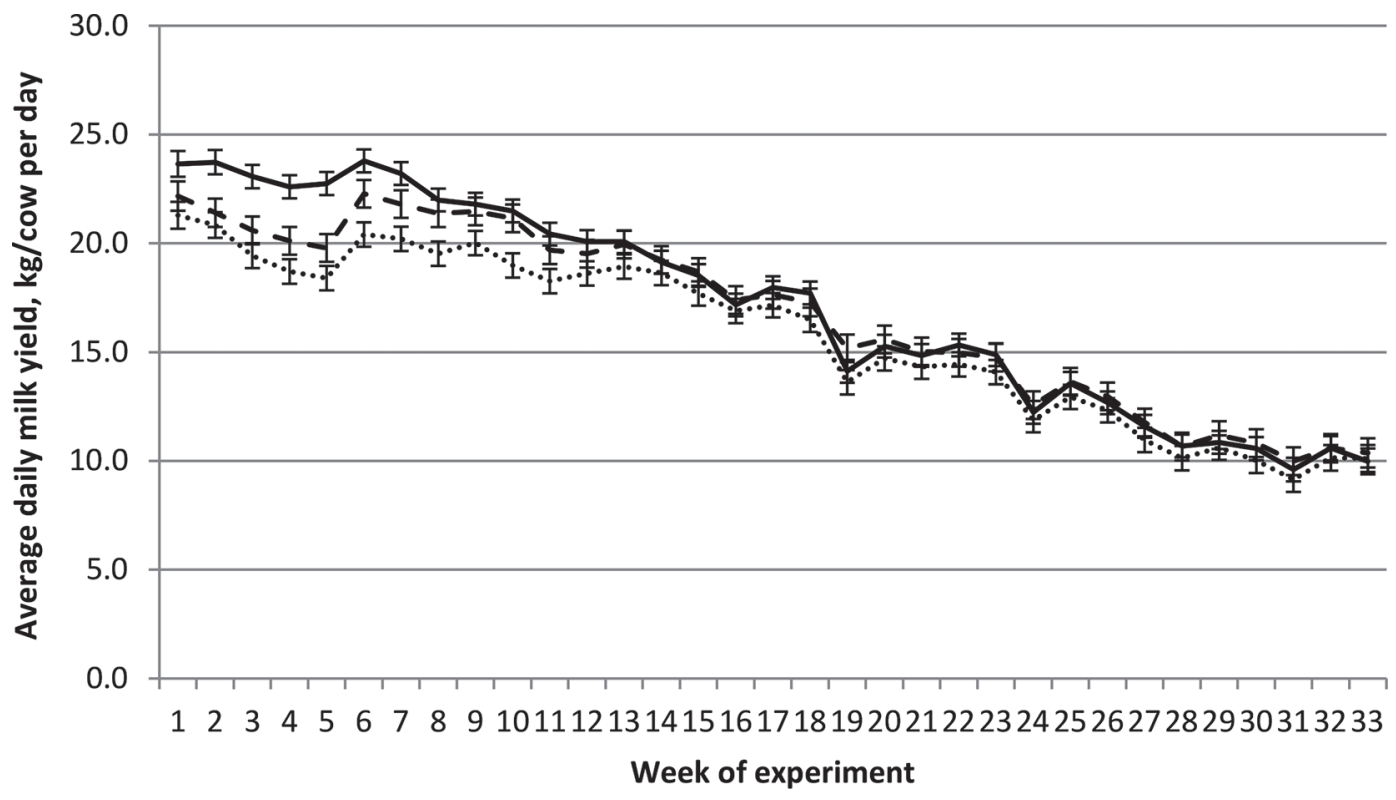

Figure 2. Average daily milk yield (kg/cow) during the full experimental period for cows given a $60 \%$ restricted pasture allowance for 2 wk (dashed line) or $6 \mathrm{wk}$ (dotted line) compared with an unrestricted control treatment (solid line). Error bars refer to the standard error of the treatment means.

\section{DISCUSSION}

The present experiment investigated the short-term and full lactation effect of reducing PA in early lactation as a method of managing short-term deficits in pasture availability in the first and second grazing rotation (February to April) when grass growth rates can be low due to prevailing climatic conditions. As farmers have become increasingly exposed to milk price volatility (Dillon et al., 2016), it is important to overcome periods of feed deficit with grazing strategies that have minimal impact on total lactation performance, animal health, and fertility and do not increase production costs on farm.

\section{Effect of Restricted Pasture Allowance and Duration of Restriction on Animal Performance}

The results from the current study confirm that restricting PA in early lactation results in an immediate decline in milk yield. They further confirm that the severity of the restriction, or in this case the longer period of restriction $(6 \mathrm{wk})$, resulted in greater losses $(-0.6 \mathrm{~kg}$ of milk/cow per day compared with 2 -wk PA restriction) during the first $10 \mathrm{wk}$ of the experiment. A $\mathrm{PA}$ representing $60 \%$ of the control PA, offered above $3.5 \mathrm{~cm}$, resulted in a Post-GSH of $2.78 \mathrm{~cm}$ during the period of restriction. This outcome equated to achieving $79 \%$ of the DMI of the control treatment $(14.3 \mathrm{~kg}$ of DM herbage removed/cow per day) and highlights the shortfalls in energy intake that restricted cows were exposed to during this period. The reduction in milk production was associated with the reduced DMI of the restricted PA animals as the nutritive value of the herbage selected by the cows did not differ. The immediate drop in daily milk production $(3.34 \mathrm{~kg} / \mathrm{cow}$; control vs. individual treatment average for respective period of $60 \% \mathrm{PA})$ equated to a $14 \%$ reduction in milk yield compared with the control treatment $(\sim 80 \%$ of DMI of control). This outcome equated to a loss in milk production of $2.92 \mathrm{~kg}$ of milk/cm reduction in PostGSH, which was similar to that reported by Ganche et al. (2013) $(-2.88 \mathrm{~kg}$ of milk/cm reduction in PostGSH) but greater than the decline reported by McEvoy et al. (2008) $(-2.11 \mathrm{~kg}$ of milk/cm reduction in PostGSH; $3.5-5 \mathrm{~cm})$. The Post-GSH imposed in the study of Ganche et al. (2013) (2.7 and $3.5 \mathrm{~cm}$ ) was similar to that achieved when PA was restricted in the current study.

Using modeling simulations, Vetharaniam et al. (2003) reported that cows offered $75 \%$ of their energy requirement could achieve $85 \%$ of their production potential if they were fed to maximal levels, which is similar to the output achieved in the current study. Following a short period of moderately restricted PA, milk yield was similar to the control. This outcome may be a result of the reactivation of quiescent cells in the mammary gland, in which diet plays an important role 
(Vetharaniam et al., 2003). The increased energy and nutrient intake associated with the increase in PA following the period of restriction may have contributed to the reactivation of cells (Delaby et al., 2009). However, a reduction in DMI may affect exocrine glands in several ways. A recent study by Herve et al. (2017) suggests that the reduction in milk yield associated with a feed restriction may be due to an increased rate of mammary epithelial cell exfoliation because they observed no difference in cell apoptosis or proliferation while DMI was restricted. Cows in the study of Herve et al. (2017) were offered $80 \%$ of their pre-experimental intake for $29 \mathrm{~d}$ (similar to the level of DMI restriction observed in the current study), and no carryover effect of the reduced DMI was observed on milk yield or on mammary epithelial cell processes following the period of restriction (7-wk carryover period). In the current study the 2-wk cows had similar milk yield within $2 \mathrm{wk}$ of the restriction and the 6-wk cows had similar milk yield from approximately 4 wk post restriction to the control. The impact of the 6 -wk restriction is similar to the more severe (offered $60 \%$ of control DMI), yet shorter (3 wk) restriction of Kay et al. (2013), who reported no carryover effect from wk 13 to 23. However, further studies have reported longer carryover effects of a 40 to $50 \%$ reduction in DMI (Roche, 2007; Burke et al., 2010) when offered for longer periods ( $5 \mathrm{wk}$; Roche, 2007 ) or later in lactation ( 60 DIM in the study of Burke et al., 2010). Vetharaniam et al. (2003) reported that as energy status decreased, milk production did not decrease at the same rate (energy status reduced from 75 to $50 \%$ of requirement, while production dropped from 85 to $68 \%$ of potential). This research demonstrates the complexity of this response and highlights the possibility that several other physiological and environmental factors may affect the animal during periods of restriction and re-alimentation.

Restricting cows in early lactation for 2 and $6 \mathrm{wk}$ reduced milk protein yield by 4.0 and $6.3 \mathrm{~kg} / \mathrm{cow}$, respectively, compared with unrestricted animals over a 10 -wk period. The average milk protein concentration of the cows restricted for $2 \mathrm{wk}$ was similar to that of the control; therefore, differences observed in milk protein yield were mainly driven by the differences observed in milk yield. Coulon and Rémond (1991) observed that an increase in energy supply increases milk protein yield first, due to increased milk yield, and then fuels an increase in milk protein concentration. Therefore, the prolonged period of restriction imposed on the 6 -wk animals may have resulted in the depression of milk protein concentration $(-1.1 \mathrm{~g} / \mathrm{kg}$ of milk) over the 10-wk period. Dessauge et al. (2011) suggested that the mammary epithelial cells of restricted animals can lack the necessary precursors to maintain milk protein 
concentration, and the PA restriction of 6 wk may also have had a greater effect on milk protein concentration because of this lack of precursors. Ganche et al. (2013) observed a loss of $0.1 \mathrm{~kg}$ protein/cow per day when cows grazed to a Post-GSH of $2.7 \mathrm{~cm}$ compared with $3.5 \mathrm{~cm}$ for a 10-wk period, which was similar to the Post-GSH achieved by restricted cows in the current study. Similarly, Kennedy et al. (2007) reported a 0.09 $\mathrm{kg} /$ cow per day reduction in milk protein yield per centimeter decrease in Post-GSH. This finding is similar to the immediate loss in milk protein yield observed in the current study of $0.1 \mathrm{~kg}$ of protein/cow per day for each centimeter reduction in Post-GSH. However, the longer restrictions of $10 \mathrm{wk}$ in the aforementioned studies did not have a carryover effect on milk protein concentration, similar to the current study. Roche (2007) reported losses of $8.8 \mathrm{~kg}$ of protein/cow when energy intake was severely restricted (64\% of control cow intakes) for $5 \mathrm{wk}$ from calving. They proposed that the loss in milk protein yield was due to insufficient metabolizable protein available in the restricted cows, which may also have contributed to the lower milk protein concentration of the 6 -wk restricted animals. Another indicator of the severity of DMI restriction is increased milk fat concentration, which can be associated with the mobilization of body tissue (Roche, 2007; Kay et al., 2013). The results of the current study are similar to the work of Ganche et al. (2013) who reported no increase in milk fat (16\% reduction in DMI compared with control).

Despite the reduction in DMI observed when a restriction was applied in early lactation, we observed no immediate effect on BCS at the end of the 2- or 6-wk period of reduced PA. During the period when PA was restricted, immediate reductions in BW (nonsignificant) were observed, with cows weighing an average of 15 and $20 \mathrm{~kg}$ less than the control for the 2 - and 6 -wk $\mathrm{PA}$, respectively; however, this finding can be attributed to differences in gut fill during the period when PA was restricted (Chilliard et al., 1991). This result is in contrast to numerous studies that have reported that when a low daily herbage allowance is offered in early lactation, a decrease in BW is often observed (Delaby et al., 2003; Kennedy et al., 2007; Ganche et al., 2013). However, the restrictions in those studies were imposed for a minimum of 10 wk in early lactation unlike the shorter period of restriction imposed in the current study. The animals used in the current study are high genetic merit animals, with particular emphasis focused on selection criteria associated with fertility, ease of maintenance, and longevity. Consequently, these animals may be predisposed to partitioning energy for maintenance and reducing milk production during pe- riods of negative energy balance. Previous research by Horan et al. (2005) demonstrated that high-durability strains of Holstein-Friesian animals (selected for fertility and maintenance traits, similar to those in the current study) lose less BW from calving to nadir compared with animals that are selected for high milk production output. Similarly, Grainger (1990) reported that animals with a lower milk production potential appeared to partition a greater proportion of energy toward BW gain than animals with a higher milk production potential when intake is restricted. It has also been suggested that animals with a lower milk production potential are not as severely restricted as high-producing animals in terms of their energy requirements (Coulon and Rémond, 1991). Therefore, the observations made in the current study may be dependent on cow type and may not be applicable in all pasture-based systems. Additionally, similar work conducted by Curran et al. (2016) demonstrated that restricting the DMI of animals in early lactation had only moderate effects on metabolic health, with no effect on resumption to cyclicity or overall fertility (Curran, 2017), which may also be dependent of the cow type used in the study.

\section{Effect of Calving Dates on Animal Performance}

One of the novel objectives of this study was to determine if the DIM of the animal when PA was restricted had a role in animal performance. Animals in the EC group were 36 DIM or greater when beginning the experiment, while those in the LC group were 35 DIM or less. The control treatment peaked in wk 6 of the experiment at a mean of 71 DIM, which suggests that the majority of the EC animals had a restricted PA imposed approaching or coinciding with peak milk production. The greater reduction in milk production observed may be associated with physiological changes related to the stage of lactation. Baird et al. (1972) observed that a cow restricted (food removed for $6 \mathrm{~d}$ ) at 59 DIM had a more rapid reduction in milk yield compared with a cow restricted at 25 DIM and suggested that milk production likely does not have the same priority in animals in later stages of early lactation in terms of the utilization of available energy, compared with animals in the early stages of lactation. The lower milk production of the EC animals may also correlate to the difference observed between the treatments in terms of BW and BCS. McCarthy et al. (2007) found that nadir BW was reached at approximately 53 DIM in animals similar to those used in the current experiment. Therefore, the greater BW and BCS of the EC animals may suggest that they partitioned a greater proportion of energy for maintenance and had a greater 
ability to reduce milk production to allow for the maintenance of body reserves (Baird et al., 1972) when PA was restricted.

\section{CONCLUSIONS}

Postgrazing sward height was the main driver of PA in the current study to maintain the desired level of use by the control treatment throughout the experimental period. Despite immediate reductions in milk production of $14 \%$ during periods of PA restriction to $60 \%$ of the PA of the control, milk production recovered to a level similar to the control when PA was increased in accordance with spring grazing management targets for Post-GSH. This outcome demonstrates that a moderate restriction ( $80 \%$ of control DMI) can be applied for up to 6 wk in early lactation with minimal implications for total lactation performance. This study demonstrates that cows with high genetic merit for fertility and maintenance are able to withstand reductions in PA in early lactation when short-term feed deficits occur. Furthermore, data from this study indicate the lower milk yield and greater BW of the EC cows is potentially due to partitioning of the restricted energy reserves toward maintenance instead of milk production during this period. However, further investigation is required to elucidate the physiological responses that occur during early lactation in response to restricted DMI in terms of energy partitioning for milk yield and maintenance. Furthermore, our study did not include measurements to investigate the restrictions applied on mammary biology and this is an area for potential future investigation.

\section{ACKNOWLEDGMENTS}

The authors thank Brendan Horan (Teagasc Moorepark) and John Roche (Ministry for Primary Industries, New Zealand) for their input into planning and designing the experiment. The authors acknowledge J. P. Murphy, A. McGrath, and M. Liddane of Teagasc Moorepark for their technical assistance and all the staff of Moorepark research farm for their care and management of the animals and assistance with measurements during the experiment. This experiment was funded by Teagasc Core Funding and Dairy Levy Funding.

\section{REFERENCES}

Baird, G. D., R. J. Heitzman, and K. K. Hibbitt. 1972. Effects of starvation on intermediary metabolism in the lactating cow. A comparison with metabolic changes occurring during bovine ketosis. Biochem. J. 128:1311-1318.
Berry, D., L. Shalloo, A. Cromie, V. Olori, and P. Amer. 2005. Economic breeding index for dairy cattle in Ireland. Irish Cattle Breeding Federation, Bandon, Ireland.

Brereton, A. J., and D. A. Mc Gilloway. 1999. Winter growth of varieties of perennial ryegrass (Lolium perenne L.). Isr. J. Agric. Res. $38: 1-12$.

Burke, C. R., Y. J. Williams, L. Hofmann, J. K. Kay, C. V. Phyn, and S. Meier. 2010. Effects of an acute feed restriction at the onset of the seasonal breeding period on reproductive performance and milk production in pasture-grazed dairy cows. J. Dairy Sci. 93:1116-1125. https://doi.org/10.3168/jds.2009-2562.

Burns, G., T. Gilliland, D. Grogan, and P. O'Kiely. 2011. Using chemometrics to develop near infrared spectroscopy (NIRS) calibrations to predict ryegrass quality. Page 135 in Agricultural Research Forum 2011, Tullamore, Co. Offaly, Ireland. Teagasc Oakpark, Carlow, Ireland.

Chilliard, Y., M. Cisse, R. Lefaivre, and B. Remond. 1991. Body composition of dairy cows according to lactation stage, somatotropin treatment, and concentrate supplementation. J. Dairy Sci. 74:3103-3116.

Coulon, J., and B. Rémond. 1991. Variations in milk output and milk protein content in response to the level of energy supply to the dairy cow: A review. Livest. Prod. Sci. 29:31-47.

Cummins, S., E. Lewis, K. M. Pierce, and E. Kennedy. 2015. The effect of pasture allowance offered for different time durations on the dry matter intake of dairy cows. Pages 87-89 in Proc. 18th Symp. European Grassland Federation, Wageningen, the Netherlands. Wageningen Academic Publishers, Wageningen, the Netherlands.

Curran, F. 2017. Nutritional effects on fertility in pasture-based systems. PhD Thesis. University College Dublin, Ireland.

Curran, F., E. Kennedy, E. Lewis, P. Lonergan, and S. Butler. 2016. Implications of acute or chronic pasture restriction on indicators of metabolic status in grass-based dairy cows. J. Anim. Sci. 94(Suppl. 5):528.

Delaby, L., P. Faverdin, G. Michel, C. Disenhaus, and J. L. Peyraud. 2009. Effect of different feeding strategies on lactation performance of Holstein and Normande dairy cows. Animal 3:891-905. https://doi.org/10.1017/S1751731109004212.

Delaby, L., J. L. Peyraud, N. Foucher, and G. Michel. 2003. The effect of two contrasting grazing managements and level of concentrate supplementation on the performance of grazing dairy cows. Anim. Res. 52:437-460. https://doi.org/10.1051/animres:2003030.

Dessauge, F., V. Lollivier, B. Ponchon, R. Bruckmaier, L. Finot, S. Wiart, E. Cutullic, C. Disenhaus, S. Barbey, and M. Boutinaud. 2011. Effects of nutrient restriction on mammary cell turnover and mammary gland remodeling in lactating dairy cows. J. Dairy Sci. 94:4623-4635. https://doi.org/10.3168/jds.2010-4012.

Dillon, P., L. Hanrahan, F. Thorne, P. Kelly, L. Shalloo, and B. Moran. 2016. Irish dairying: Well positioned for the upturn. Pages 8-27 in Technologies for Success, Teagasc National Dairy Conference, Cork and Westmeath. Teagasc Moorepark, Cork, Ireland.

Edmonson, A., I. Lean, L. Weaver, T. Farver, and G. Webster. 1989. A body condition scoring chart for Holstein dairy cows. J. Dairy Sci. 72:68-78.

Finneran, E., P. Crosson, P. O'Kiely, L. Shalloo, D. Forristal, and M. Wallace. 2010. Simulation modelling of the cost of producing and utilising feeds for ruminants on Irish farms. J. Farm Manag. 14:95-116.

Ganche, E., L. Delaby, M. O'Donovan, T. Boland, and E. Kennedy. 2013. Direct and carryover effect of post-grazing sward height on total lactation dairy cow performance. Animal 7:1390-1400. https: //doi.org/10.1017/S1751731113000451.

Grainger, C. 1990. Effect of stage of lactation and feeding level on milk yield response by stall-fed dairy cows to change in pasture intake. Aust. J. Exp. Agric. 30:495-501.

Hanrahan, L., A. Geoghegan, M. O'Donovan, V. Griffith, E. Ruelle, M. Wallace, and L. Shalloo. 2017. Pasturebase Ireland: A grassland decision support system and national database. Comput. Electron. Agric. 136:193-201. https://doi.org/10.1016/j.compag 2017.01.029. 
Herve, L., M. Veron, P. Lamberton, S. Wiart, P. Debournoux, S. Philau, C. Mustière, H. Quesnel, and M. Boutinaud. 2017. Feed restriction increases mammary epithelial cell exfoliation rate in dairy cows. J. Anim. Sci. 95(Suppl. 4):170-171. (Abstr.)

Horan, B., P. Dillon, P. Faverdin, L. Delaby, F. Buckley, and M. Rath. 2005. The interaction of strain of Holstein-Friesian cows and pasture-based feed systems on milk yield, body weight, and body condition score. J. Dairy Sci. 88:1231-1243.

Hurtado-Uria, C., D. Hennessy, L. Shalloo, D. O'Connor, and L. Delaby. 2013. Relationships between meteorological data and grass growth over time in the south of Ireland. Ir. Geogr. 46:175-201. https://doi.org/10.1080/00750778.2013.865364.

Kay, J. K., C. V. C. Phyn, A. G. Rius, S. R. Morgan, T. M. Grala and J. R. Roche. 2013. Once-daily milking during a feed deficit decreases milk production but improves energy status in early lactating dairy cows. J. Dairy Sci. 96:6274-6284. https://doi.org/10 $.3168 /$ jds.2012-6167.

Kennedy, E., J. Curran, B. Mayes, M. McEvoy, J. P. Murphy, and M. O'Donovan. 2011. Restricting dairy cow access time to pasture in early lactation: The effects on milk production, grazing behaviour and dry matter intake. Animal 5:1805-1813. https://doi.org/10 $.1017 /$ S1751731111000826.

Kennedy, E., L. Delaby, B. Horan, J. Roche, and E. Lewis. 2015. Duration is important in the effect of pasture allowance restriction on subsequent milk production, in early lactation. Pages 110-112 in Proc. 18th Symp. European Grassland Federation, Wageningen, the Netherlands. Wageningen Academic Publishers, Wageningen, the Netherlands.

Kennedy, E., M. O'Donovan, F. P. O'Mara, J. P. Murphy, and L. Delaby. 2007. The effect of early-lactation feeding strategy on the lactation performance of spring-calving dairy cows. J. Dairy Sci. 90:3060-3070. https://doi.org/10.3168/jds.2006-579.

McCarthy, S., D. P. Berry, P. Dillon, M. Rath, and B. Horan. 2007. Influence of Holstein-Friesian strain and feed system on body weight and body condition score lactation profiles. J. Dairy Sci. 90:18591869. https://doi.org/10.3168/jds.2006-501.

McEvoy, M., E. Kennedy, J. Murphy, T. Boland, L. Delaby, and M. O'Donovan. 2008. The effect of herbage allowance and concentrate supplementation on milk production performance and dry matter intake of spring-calving dairy cows in early lactation. J. Dairy Sci. 91:1258-1269. https://doi.org/10.3168/jds.2007-0710.

Roche, J. R. 2007. Milk production responses to pre- and postcalving dry matter intake in grazing dairy cows. Livest. Sci. 110:12-24. https://doi.org/10.1016/j.livsci.2006.08.016.

Vetharaniam, I., S. Davis, M. Upsdell, E. Kolver, and A. Pleasants. 2003. Modeling the effect of energy status on mammary gland growth and lactation. J. Dairy Sci. 86:3148-3156. 